\title{
OBTAINING OF COUMARONE-INDENE RESINS BASED ON LIGHT FRACTION OF COAL TAR 3. COUMARONE-INDENE RESINS WITH METHACRYLIC FRAGMENTS
}

\author{
Michael Bratychak ${ }^{1, *}$, Olena Astakhova ${ }^{1}$, Yuriy Prysiazhnyi $^{1}$, M ariia Shved $^{1}$, \\ Olena Shyshchak ${ }^{1}$, Jacek Namiesnik ${ }^{2}$, Marta Plonska- Brzezinska ${ }^{3}$
}

https://doi.org/10.23939/chcht12.03.379

\begin{abstract}
The method for obtaining coumarone-indene resins with methacrylic fragments (CIRM) was developed with the addition of methyl methacrylate, using a light fraction of coal tar and its fraction boiling within 423$463 \mathrm{~K}$. CIRM was obtained via radical cooligomerization using 2,2'-azobis (2-methyl-propionitrile) as the initiator. The effect of the initiator amount, temperature and reaction time on the yield, softening temperature and molecular weight of CIRM has been established. The structure of the synthesized CIRM has been confirmed by IR and NMR spectroscopy. It is proposed to use CIRM as a polymer component of bitumen-polymeric mixtures (BPS). The effect of CIRM amount, temperature and time on the main characteristics of BPS has been studied.
\end{abstract}

Keywords: coumarone-indene resin, coal tar, methyl methacrylate, azoinitiator, IR spectroscopy, NMR spectroscopy, bitumen-polymeric mixture.

\section{Introduction}

When building modern roads, petroleum bitumen and polymeric additives are used as components of road materials [1-3]. It is recommended to use elastomers, thermoplastic and reactive polymers, as well as various resins as polymeric additives [1]. The introduction of the polymeric component into the composition of road bitumen significantly improves the performance characteristics of the coating, in particular adhesion to mineral fillers, elasticity and reduces brittleness $[4,5]$.

\footnotetext{
${ }^{1}$ Lviv Polytechnic National University

12, S.Bandery St., 79013 Lviv, Ukraine

${ }^{2}$ Gdansk University of Technology,

11/12 G. Narutowicza St., 80233 Gdansk, Poland

${ }^{3}$ University of Bialystok,

1, Hurtowa St., 15-399 Bialystok, Poland

mbratychak@gmail.com

(C) Bratychak M., Astakhova O., Prysiazhnyi Y., Shved M., Shyshchak O., Namiesnik J., Plonska-Brzezinska M., 2018
}

Over the past few years, the researchers of the Department of Chemical Technology of Oil and Gas Processing at Lviv Polytechnic National University have been conducting studies on the possibility of using petroleum [6-8], phenol formaldehyde [9] and epoxy [10] resins as polymeric additives. A particular attention should be paid to petroleum resins, because they are synthesized from liquid by-products obtained after hydrocarbon raw materials pyrolysis with the aim of ethylene production [11-13]. Using the $\mathrm{C}_{9}$ fraction of liquid pyrolysis products containing such unsaturated hydrocarbons as styrene, vinyl toluenes, dicyclopentaiene, indene, etc., petroleum resins with epoxy [14], carboxy [15] and hydroxy [16] groups were synthesized. Petroleum resins with various functional groups are used as additives during oil tar oxidation to bitumen and for the preparation of bitumen-polymer mixtures [17]. The joint oxidation of tar and petroleum resins (PRs) was carried out at $523 \mathrm{~K}$ for $3 \mathrm{~h}$ with an air volumetric flow rate of $2.5 \mathrm{~min}^{-1}$. The amount of PRs in the raw material mixture was $1-10 \mathrm{wt} \%$. The increase in the amount of PRs with epoxy or carboxy groups raises the softening temperature of bitumen, its ductility and adhesion [8, 17]. At the same time, the penetration of bitumen, which characterizes its hardness, decreases. The optimum amount of PRs in such a mixture is $5 \mathrm{wt} \%$.

When preparing bitumen-polymeric mixtures, PRs with epoxy, carboxy and hydroxy groups [17] have been studied as polymer components. As in the previous case, the amount of PRs in the mixture ranged from 1 to $10 \mathrm{wt} \%$. The introduction of PRs in bitumen makes it possible to significantly increase the adhesion of commercial bitumen to mineral fillers, with the best results achieved in the case of using PRs with carboxy groups in an amount of $5 \mathrm{wt} \%$ [17].

Good results in the creation of bitumen-polymeric mixtures are also achieved in the case of using phenolformaldehyde and epoxy resins containing different 
functional groups $[8,9]$. The disadvantage of such mixures is the expensiveness of resins used. Therefore, the search for the raw materials, which would give the opportunity to obtain cheap resins (polymers), is still relevant.

It is known [18] that a coal tar resin is a by-product of coal coking. As a result of the coal tar rectification, an indene-coumarone fraction (ICF) [19] and a light fraction of coal tar (LFCT) are obtained. Both fractions contain sufficient amounts of indene, coumarone, styrene and other unsaturated compounds, and therefore they are used to produce the so-called coumarone-indene resins (CIR) which may be used as polymer components for the creation of bitumen-polymer mixtures [20]. CIR with functional groups, namely epoxy and carboxy groups, are described by M. Bratychak et al. [21, 22]. Functional groups in the CIR structure increase the adhesion properties of the final products.

This work deals with the obtaining coumaroneindene resins with methacrylic fragments (CIRM) on the basis of LFCT.

\section{Experimental}

\subsection{M aterials}

The raw materials for CIRM synthesis were light fraction of coal tar (LFCT), produced at JSC "Zaporizhkoks" (Ukraine), and indene-coumarone fraction based on it (ICF, 423-463 K). The content of the components is described in [21].

Monomer with methacrylic fragment was methyl methacrylate (MMA) produced by VWR Prolabo Chemicals (CAS: 80-62-6), density $d_{4}^{20}=0.935$. Apart from MMA the styrene was used as an additional monomer. It was dried before the experiments with solid alkali and then purified by distillation at $323 \mathrm{~K}$ under residue pressure of $300-400 \mathrm{~Pa}$. Its characteristics: refractive index $n_{D}^{20}=1.5471$ (literature value $n_{D}^{20}=1.5468$ ); density $d_{4}^{20}=0.650$ (literature value $\left.d_{4}^{20}=0.9059\right)$ [23].

2,2'-Azobis(2-methyl-propionitrile) as $0.2 \mathrm{M}$ solution in toluene (AMP, purchased from Aldrich) was the cooligomerization initator. Its characteristics: $d_{4}^{20}=0.858, n_{D}^{20}=1.495$.

Toluene was purchased from Aldrich. The petroleum ether was a fraction with a boiling range of $313-343 \mathrm{~K}, d_{4}^{20}=0.650$.

Bitumen characteristics: softening temperature $319 \mathrm{~K}$, penetration $70 \cdot 10^{-4} \mathrm{~m}$, ductility $63 \cdot 10^{-2} \mathrm{~m}$, adhesion to glass $47 \%$.

\subsection{Analytical Determination}

The number-average molecular weight $\left(M_{n}\right)$ of the synthesized CIR was determined using cryoscopy in benzene. The softening temperature of CIR was determined using a ring-and-ball method [24]. Penetration [25], softening temperature [26], ductility [24] and adhesion [27] were determined according to the procedures described in the mentioned references.

\subsection{Spectral M easurements}

Infrared spectra of CIR with methacrylic fragments were measures using Nicolet IR 200 (Thermo Electron Co., USA) with Golden Gate ATR diamond crystal. Every spectrum was recorded with $4 \mathrm{~cm}^{-1}$ resolution. Samples were prepared as powders or were dissolved in acetone.

${ }^{1} \mathrm{H}$ and ${ }^{13} \mathrm{C}$ NMR spectra were recorded at $400 \mathrm{MHz}$ and $100 \mathrm{~Hz}$, respectively, using Bruker Avance II 400 spectrometer (Poland) in deuterochloroform at room temperature.

\subsection{Synthesis Procedure}

\subsubsection{CIRM synthesis}

LFCT or ICF cooligomerization was carried out in metal ampoules by the capacity of $100 \mathrm{ml}$. The ampoules were loaded with the initial fraction, monomer and initiator, then blown with an inert gas, closed and placed into a thermostat. After finishing the process the ampoules were cooled to room temperature and the matter was precipitated using petroleum ether. The precipitated product was dried in a vacuum oven at $313 \mathrm{~K}$ till the weight became constant. The yield relative to the initial reaction mixture was calculated according to the formula (1)

$$
X=\frac{m_{r}}{m_{i n}} \cdot 100 \%
$$

where $m_{r}$ - weight of the resulted resin, $\mathrm{g} ; m_{i n}$ - weight of the initial reaction mixture, $\mathrm{g}$.

\subsubsection{Preparation of bitumen-polymeric mixtures}

Bitumen was heated in a reactor till definite temperature, then CIRM was added and mixed $(\operatorname{Re}=1200)$ for a definite time.

\section{Results and Discussion}

\subsection{Coumarone-Indene Resins with M ethacrylic Fragments (CIRM)}

The studied LFCT and ICF contain indene, coumarone and styrene [21].Under certain conditions they 
are capable of cooligomerization and formation of coumarone indene resins. At the same time, it is evident that concentration of such compounds is low, which requires the addition of styrene to the initial mixture to increase the yield of resins $[21,22]$.

The effect of the reaction mixture composition on the yield and characteristics of CIRM is demonstrated in Table 1. When adding styrene to LFCT in the absence of MMA, the CIRM yield does not exceed $5.1 \%$ (CIRM-I). The decrease in styrene and gradual increase in MMA concentrations increase the CIRM yield to $25.5 \%$ (CIRM$\mathrm{V})$. At the same time the molecular weight of the synthesized resins and the softening temperature decrease. So, we may assert that using MMA it is unnecessary to add styrene to increase the CIRM yield.

The effect of initiator concentration on the yield and characteristics of CIRM is represented in Table 2. The increase in AMP concentration to $0.0407 \mathrm{~mol} / \mathrm{l}$ positively affects the yield of the resulting product $(29.7 \%$, CIRMVII). Further increase in AMP amount to $0.0554 \mathrm{~mol} / \mathrm{l}$ practically does not affect both the CIRM yield and its characteristics. Taking into account that at AMR concentration of $0.0226 \mathrm{~mol} / \mathrm{l}$ a sufficiently high yield of CIRM is achieved (CIRM-V), and the resulting resin has the highest molecular weight and softening temperature, such amount of initiator was chosen for the future experiments.

One can see from Table 3 that at optimum AMR concentration and reaction temperature of $353 \mathrm{~K}$, the CIRM yield is $23.1 \%$ (CIRM-X) already after $4 \mathrm{~h}$. Increasing the reaction time to $6 \mathrm{~h}$ makes it possible to obtain resin with $25.5 \%$ yield (CIRM-V), which is characterized by a molecular weight of $600 \mathrm{~g} / \mathrm{mol}$ and a softening temperature of $364 \mathrm{~K}$. Further increase in the reaction time to $8-10 \mathrm{~h}$ practically does not change the resin yield and molecular weight.

Analyzing the data presented in Table 4, we note that the decrease in the reaction temperature to $343 \mathrm{~K}$ leads to the decrease in both resin yield and molecular weight, as well. At $363 \mathrm{~K}$ the resin yield slightly increases, the softening temperature decreases and molecular weight increases in comparison with those values observed at $343 \mathrm{~K}$. This can be explained by the fact that at high temperature $(363 \mathrm{~K})$ a rapid decomposition of the initiator and an acceleration of radicals recombination occur. Under these conditions, not all monomers are capable of oligomerization, resulting in the decrease of the CIRM yield. The optimum temperature, at which the highest yield is achieved, is $353 \mathrm{~K}$.

Table 1

Effect of the reaction mixture composition on CIRM characteristics

\begin{tabular}{|c|c|c|c|c|c|c|c|}
\hline \multicolumn{2}{|c|}{ Composition of the initial mixture, $\mathrm{g}$} & \multicolumn{5}{|c|}{ CIRM characteristics } \\
\hline LFCT & Styrene & MMA & \multirow{2}{*}{$\begin{array}{c}\text { CIRM } \\
\text { symbol }\end{array}$} & $\begin{array}{c}\text { Yield relative to the } \\
\text { initial mixture }\end{array}$ & $\begin{array}{c}\text { Softening } \\
\text { temperature, K }\end{array}$ & $\begin{array}{c}M_{n}, \\
\mathrm{~g} / \mathrm{mol}\end{array}$ \\
\hline 45.2 & 9.09 & 0 & CIRM-I & 2.8 & 5.1 & - & - \\
\hline 45.2 & 7.27 & 1.87 & CIRM-II & 3.8 & 7.0 & - & 840 \\
\hline 45.2 & 3.64 & 5.61 & CIRM-III & 4.3 & 13.4 & 382 \\
\hline 45.2 & 1.82 & 7.48 & CIRM-IV & 9.5 & 17.4 & 375 & 670 \\
\hline 45.2 & 0 & 9.35 & CIRM-V & 13.9 & 25.5 & 379 & 600 \\
\hline
\end{tabular}

Notes: reaction temperature $353 \mathrm{~K}$, time $6 \mathrm{~h}$, AMP concentration $0.0226 \mathrm{~mol} / \mathrm{l}$.

Table 2

Effect of AMP concentration on CIRM characteristics

\begin{tabular}{|c|c|c|c|c|c|c|c|}
\hline \multicolumn{3}{|c|}{ Composition of the initial mixture, $g$} & \multicolumn{5}{|c|}{ CIRM characteristics } \\
\hline \multirow[t]{2}{*}{ AMP, mol/l } & \multirow[t]{2}{*}{ LFCT, g } & \multirow[t]{2}{*}{ MMA, g } & \multirow[t]{2}{*}{ CIRM symbol } & \multicolumn{2}{|c|}{$\begin{array}{c}\text { Yield relative to the } \\
\text { initial mixture }\end{array}$} & \multirow{2}{*}{$\begin{array}{c}\text { Softening } \\
\text { temperature, } \mathrm{K}\end{array}$} & \multirow{2}{*}{$\begin{array}{c}M_{n}, \\
\mathrm{~g} / \mathrm{mol}\end{array}$} \\
\hline & & & & $\mathrm{g}$ & $\%$ & & \\
\hline 0.0097 & 45.2 & 9.35 & CIRM-VI & 5.1 & 9.3 & 365 & 540 \\
\hline 0.0226 & 45.2 & 9.35 & CIRM-V & 13.9 & 25.5 & 364 & 600 \\
\hline 0.0407 & 45.2 & 9.35 & CIRM-VII & 16.2 & 29.7 & 337 & 510 \\
\hline 0.0554 & 45.2 & 9.35 & CIRM-VIII & 16.0 & 29.3 & 341 & 490 \\
\hline
\end{tabular}

Notes: reaction temperature $353 \mathrm{~K}$, time $6 \mathrm{~h}$. 
Table 3

Effect of reaction time on CIRM characteristics

\begin{tabular}{|c|c|c|c|c|c|}
\hline \multirow{3}{*}{ Time, $\mathrm{h}$} & \multicolumn{5}{|c|}{ CIRM characteristics } \\
\cline { 2 - 4 } & \multirow{2}{*}{ CIRM symbol } & Yield relative to the initial mixture & \multirow{2}{*}{ Softening temperature, $\mathrm{K}$} & \multirow{2}{*}{$M_{n}, \mathrm{~g} / \mathrm{mol}$} \\
\cline { 3 - 6 } & & $\mathrm{g}$ & $\%$ & 318 & 470 \\
\hline 2 & CIRM-IX & 10.1 & 18.5 & 328 & 500 \\
\hline 4 & CIRM-X & 12.6 & 23.1 & 364 & 600 \\
\hline 6 & CIRM-V & 13.9 & 25.5 & 321 & 590 \\
\hline 8 & CIRM-XI & 13.9 & 25.3 & 325 & 650 \\
\hline 10 & CIRM-XII & 13.8 & & & \\
\hline
\end{tabular}

Notes: reaction temperature $353 \mathrm{~K}$; AMP concentration $0.0226 \mathrm{~mol} / \mathrm{l}$. Composition of the initial mixture, g: LFCT - 45.2; MMA - 9.35.

Table 4

Effect of reaction temperature on CIRM characteristics

\begin{tabular}{|c|c|c|c|c|c|}
\hline \multirow{2}{*}{ Temperature, $\mathrm{K}$} & \multicolumn{4}{|c|}{ CIRM characteristics } \\
\cline { 2 - 4 } & \multirow{2}{*}{ CIRM symbol } & Yield relative to the initial mixture & \multirow{2}{*}{ Softening temperature, K } & \multirow{2}{*}{$M_{n}, \mathrm{~g} / \mathrm{mol}$} \\
\cline { 3 - 6 } & & $\mathrm{g}$ & $\%$ & 367 & 510 \\
\hline 343 & CIRM-XIII & 8.6 & 25.5 & 364 & 600 \\
\hline 353 & CIRM-V & 13.9 & 18.5 & 359 & 720 \\
\hline 363 & CIRM-XIV & 10.1 & 15.8 & & 5 \\
\hline
\end{tabular}

Notes: reaction time 6 h; AMP concentration 0.0226 mol/l. Composition of the initial mixture, g: LFCT - 45.2; MMA - 9.35.

In general, analyzing the results shown in Tables 24 it can be concluded that in the case of the use of LFCT and MMA and the use of AMP as an initiator, the production of indene-coumarone resins containing fragments of MMA should be performed under the following conditions:

- reaction temperature $353 \mathrm{~K}$;

- reaction time $6 \mathrm{~h}$;

- concentration of AMP in the reaction mixture $0.0226 \mathrm{~mol} / \mathrm{l}$

- MMA content in the reaction mixture $9.35 \mathrm{~g}$.

The resulting resin (CIRM-V) is characterized by yield of $25.5 \%$, softening temperature of $364 \mathrm{~K}$ and molecular weight of $600 \mathrm{~g} / \mathrm{mol}$.

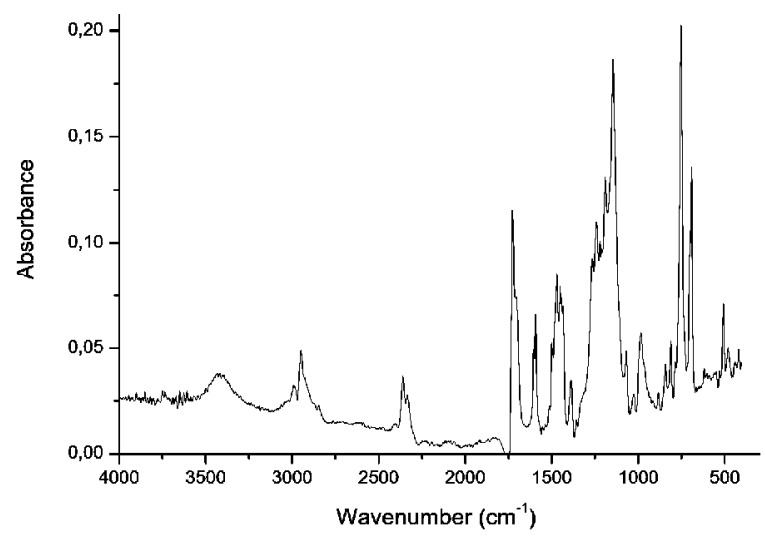

a)
The same synthesis conditions were used to obtain resins based on ICF (CIRM-XV). The initial mixture composition is: ICF $189.0 \mathrm{~g}$; MMA $37.4 \mathrm{~g}$; AMP concentration $0.0226 \mathrm{~mol} / \mathrm{l}$. The resulting resin $(\mathrm{CIRM}-\mathrm{XV})$ is characterized by the yield of $26.4 \%$, softening temperature of $359 \mathrm{~K}$ and molecular weight of $530 \mathrm{~g} / \mathrm{mol}$.

So, the characteristics of both synthesized resins are similar.

\subsection{Spectroscopic Investigations}

To confirm the structure of the synthesized resins we used IR- and NMR-spectroscopy (Figs. 1 and 2-3, respectively).

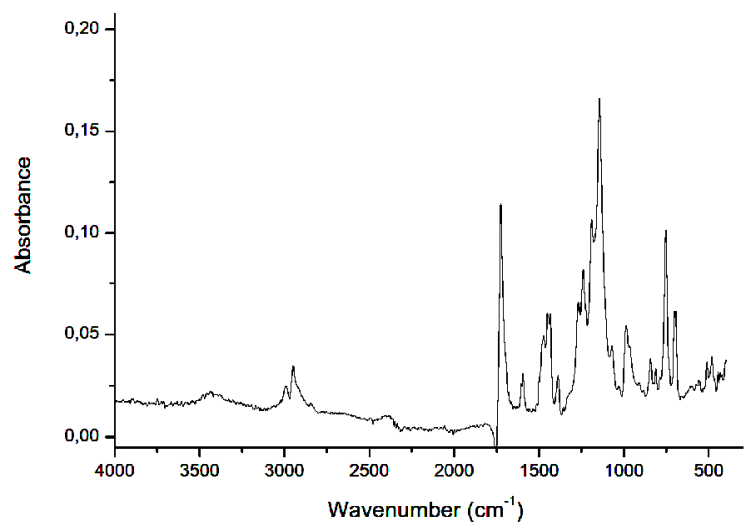

b)

Fig. 1. IR-spectra of CIRM-V (a) and CIRM-XV (b) 


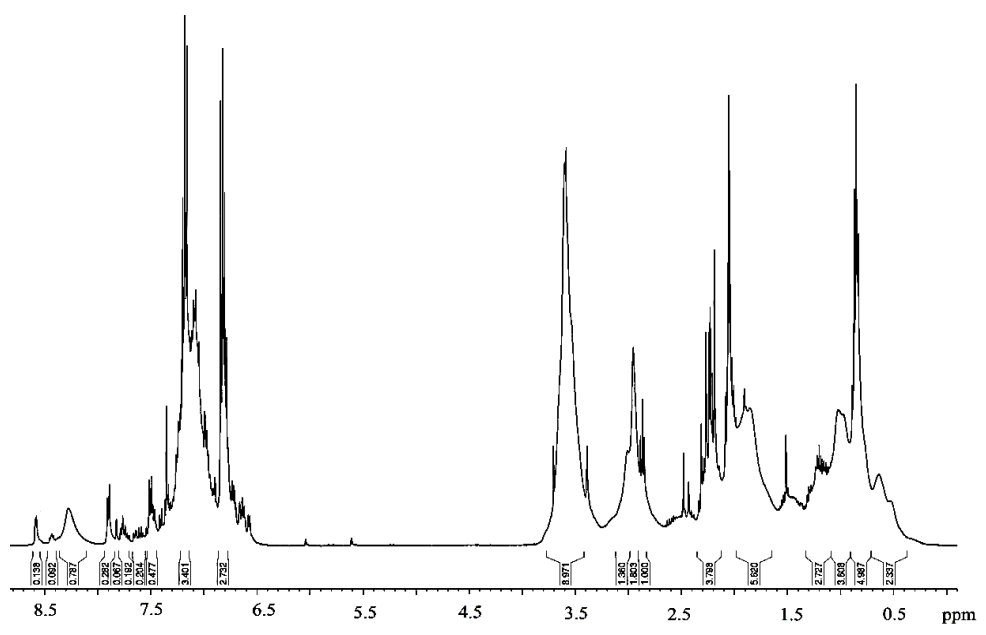

Fig. 2. H NMR spectrum of CIRM-XV

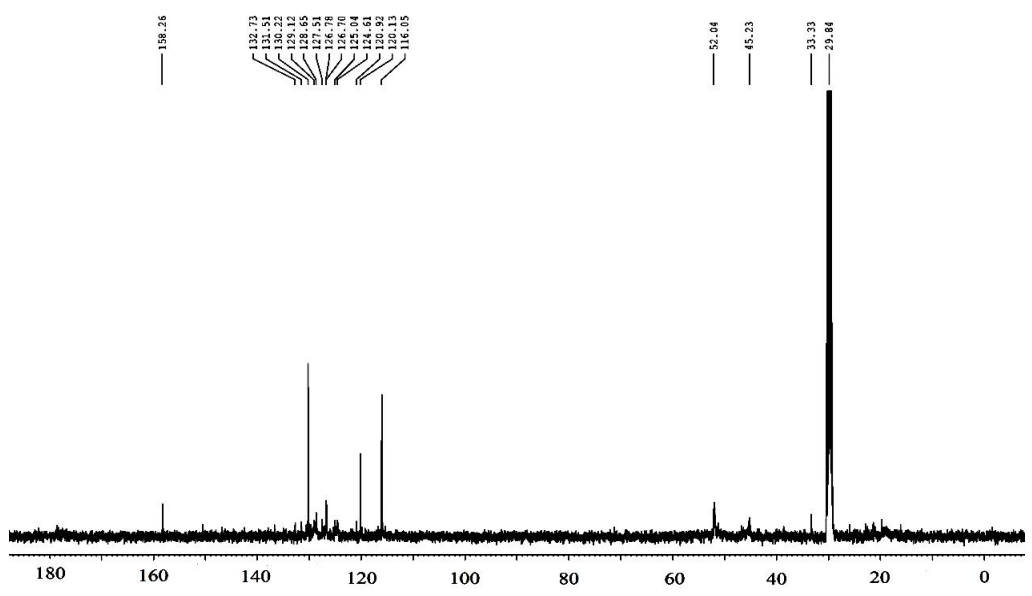

Fig. 3. 13C NMR spectrum of CIRM-XV

Analyzing the IR spectra of CIRM-V and CIRMXV (Fig. 1), we observe their identity. The presence of methacrylic fragments in the synthesized resins is confirmed by the stretching vibrations $\left(v_{\mathrm{C}=\mathrm{O}}\right)$ of the carbonyl group at $1725 \mathrm{~cm}^{-1}$ (Fig. 1a) and $1724 \mathrm{~cm}^{-1}$ (Fig. 1b). Moreover, we observe stretching vibrations at 3428 and $3427 \mathrm{~cm}^{-1}$ (Figs. 1a and 1b, respectively), which are typical of the carbonyl group in esters. The presence of $-\mathrm{CH}_{3}$ group in $-\mathrm{C}-\mathrm{O}-\mathrm{CH}_{3}$ is proved by symmetric deformation vibrations at $1386 \mathrm{~cm}^{-1}$. The group $\mathrm{C}-\mathrm{O}-\mathrm{C}$, which is a part of the methacrylic fragment, is confirmed by asymmetric stretching vibrations at 1145 and $1143 \mathrm{~cm}^{-1}$. The presence of the indene fragment is proved by asymmetric stretching vibrations at $2950 \mathrm{~cm}^{-1}$ of $\mathrm{CH}_{2}$ group, which is directly bounded with the benzene ring in the indene molecule. The fragments of coumarone included in the structure of CIRM-V and CIRM-XV are proved by stretching vibrations at 1190 and $1189 \mathrm{~cm}^{-1}$ of $\mathrm{C}-\mathrm{O}-\mathrm{C}$ group in the coumarone molecule. The benzene rings that can correspond to the styrene, coumarone and indene molecules are proved by the presence of stretching vibrations within $1592-1434 \mathrm{~cm}^{-1}$, as well as deformation vibrations at 752, 696 and $692 \mathrm{~cm}^{-1}$ of $\mathrm{CH}$ group in the substituted benzene rings. The residues of azoinitiator, which are part of the resulting resins structure, are proved by stretching vibrations of $-\mathrm{C} \equiv \mathrm{N}$ group at 2377 and $2358 \mathrm{~cm}^{-1}$.

The fragment of the methacrylate group $\mathrm{CH}_{3}-\mathrm{O}$ in ${ }^{1} \mathrm{H} N M R$ spectrum (Fig. 2) is confirmed by protons signals at 3.54-3.65 ppm, as well as in ${ }^{13} \mathrm{C}$ NMR spectrum by chemical shifts at 45.23 and $52.04 \mathrm{ppm}$ (Fig. 3). The $\mathrm{CH}_{3}$ group, which is found both in the methacrylic fragment and in the residues of azoinitiator, is proved by protons in the region of $0.79-0.87 \mathrm{ppm}$ (Fig. 2) and by chemical shifts at 29.04 and $33.33 \mathrm{ppm}$ (Fig. 3). The indene fragments that correspond to $\mathrm{CH}_{2}$ group (Fig. 2) are confirmed by protons in the 1.67-1.88 ppm region. The presence of aromatic rings in the structure of CIRM-XV 
was proven by protons in the region of $6.6-8.0 \mathrm{ppm}$ (Fig. 2) and chemical shifts in the region of $116-132 \mathrm{ppm}$ (Fig. 3). The presence of $-\mathrm{C} \equiv \mathrm{N}$ group is confirmed by a chemical shift at 120 ppm (Fig. 3).

So, coumarone-indene resins with indene, coumarone, styrene and methacrylic fragments are produced via copolymerization of LFCT and ICF using AMP as the initiator.

\subsection{Bitumen-Polymeric Compositions}

To create bitumen-polymeric mixtures (BPS), we used bitumen, the characteristics of which are given in Subsection 2.1. CIRM-XV was used as a polymer component.

It was necessary to determine the effect of polymer component amount, the temperature and time of BPM preparation on its characteristics. The results are shown in Tables 5-7.

Bitumen without the addition of CIRM-XV was studied for the comparison (Table 5). The amount of resin was $1,2,3$ and 5 wt $\%$ relative to the total BPM amount. The introduction of resin from 1 to $5 \mathrm{wt} \%$ virtually leads to a slight increase in a softening temperature but penetration and ductility decrease. At the same time, the adhesion of the formed mixtures increases significantly.
From Table 5 it can be concluded that the best results related to adhesion are achieved with CIRM-XV amount of $1 \mathrm{wt} \%$. Under these conditions, the characteristics of the resulting mixture practically coincide with the characteristics of bitumen without a polymeric component, except the adhesion, which is twice higher.

The next step was to study the effect of the process time and temperature on BPM characteristics. We observe that BPM prepared for $0.5 \mathrm{~h}$ (Table 6) have the same characteristics, compared with that prepared for $1 \mathrm{~h}$. The exception is adhesion, which is $96 \%$ (cf. $90 \%$ for $0.5 \mathrm{~h}$ ). Further increase in the process time leads to the increase in the softening temperature, but at the same time the ductility decreases and the adhesion of the formed BPM decreases sharply. This indicates that $1 \mathrm{~h}$ is the most favorable time to prepare BPM.

The effect of temperature on BPM characteristics are demonstrated in Table 7. Increasing the temperature up to $483 \mathrm{~K}$ improves the softening temperature, but worsens penetration and ductility. On the other hand, the temperature of $443 \mathrm{~K}$ does not allow to receive BPM, which would be characterized by a sufficient adhesion.

Table 5

Effect of polymer component amount on BPM characteristics

\begin{tabular}{|l|c|c|c|c|}
\hline \multicolumn{1}{|c|}{ BPM composition, wt \% } & $\begin{array}{c}\text { Softening temperature, } \\
\text { K }\end{array}$ & $\begin{array}{c}\text { Penetration at 298 K, } \\
0.1 \mathrm{~mm}\end{array}$ & $\begin{array}{c}\text { Ductility at 298 K, } \\
\text { cm }\end{array}$ & Adhesion, \% \\
\hline Bitumen 100.0, CIRM-XV 0.0 & 319 & 70 & 63 & 47 \\
\hline Bitumen 99.0, CIRM-XV 1.0 & 320 & 68 & 60 & 96 \\
\hline Bitumen 98.0, CIRM-XV 2.0 & 320 & 69 & 58 & 95 \\
\hline Bitumen 97.0, CIRM-XV 3.0 & 321 & 67 & 55 & 94 \\
\hline Bitumen 95.0, CIRM-XV 5.0 & 320 & 66 & 56 & 95 \\
\hline
\end{tabular}

Notes: temperature $463 \mathrm{~K}$, time $1 \mathrm{~h}$.

Table 6

Effect of preparation time on BPM characteristics

\begin{tabular}{|c|c|c|c|c|}
\hline Preparation time, $\mathrm{h}$ & $\begin{array}{c}\text { Softening temperature, } \\
\mathrm{K}\end{array}$ & $\begin{array}{c}\text { Penetration at } 298 \mathrm{~K}, \\
0.1 \mathrm{~mm}\end{array}$ & $\begin{array}{c}\text { Ductility at 298 K, } \\
\mathrm{cm}\end{array}$ & Adhesion, \% \\
\hline 0.5 & 319 & 69 & 65 & 90 \\
\hline 1.0 & 320 & 68 & 60 & 96 \\
\hline 2.0 & 321 & 68 & 55 & 10 \\
\hline
\end{tabular}

Notes: BPM composition, wt \%: bitumen 99.0 and CIRM-XV 1.0; temperature $463 \mathrm{~K}$.

Table 7

Effect of preparation temperature on BPM characteristics

\begin{tabular}{|c|c|c|c|c|}
\hline Preparation temperature, K & $\begin{array}{c}\text { Softening temperature, } \\
\text { K }\end{array}$ & $\begin{array}{c}\text { Penetration at 298 K, } \\
0.1 \mathrm{~mm}\end{array}$ & $\begin{array}{c}\text { Ductility at 298 K, } \\
\mathrm{cm}\end{array}$ & Adhesion, \% \\
\hline 443 & 319 & 69 & 64 & 28 \\
\hline 463 & 320 & 68 & 60 & 96 \\
\hline 483 & 321 & 66 & 53 & 94 \\
\hline
\end{tabular}

Notes: BPM composition, wt \%: bitumen 99.0 and CIRM-XV 1.0; time $1 \mathrm{~h}$. 
Thus, on the basis of the conducted studies it can be stated that the introduction of CIRM-XV into the bitumen leads to a significant increase in the adhesion. The optimum amount of CIRM-XV is $1 \mathrm{wt} \%$. The process temperature should be $463 \mathrm{~K}$, process time $1 \mathrm{~h}$. The obtained BPM has practically twice the higher adhesion, compared with bitumen without a polymeric component.

\section{Conclusions}

Coumarone-indene resins containing methacrylic fragments (CIRM) were obtained via cooligomerization of the light fraction of coal tar (LFCT) or its indene-coumarone fraction boling within $423-463 \mathrm{~K}$ with the addition of methyl methacrylate. 2,2'-Azobis(2-methyl-propionitrile) was used as the initiator. The highest CIRM yield relative to LFCT was achieved at $353 \mathrm{~K}$ for $6 \mathrm{~h}$ with the initiator concentration of $0.0226 \mathrm{~mol} / \mathrm{l}$. The resulting CIRMs are characterized by the yield of $25.5 \%$, the softening temperature of $364 \mathrm{~K}$, and the molecular weight of $600 \mathrm{~g} / \mathrm{mol}$. The presence of methacrylic fragments was confirmed by the IR absorption band at $1725 \mathrm{~cm}^{-1}$, which corresponds to the stretching vibration of $\mathrm{C}=\mathrm{O}$ group in esters, and $\mathrm{CH}_{3}-\mathrm{O}$ group in the ${ }^{1} \mathrm{H} \mathrm{NMR}$ spectrum, confirmed by protons signals at $3.54-3.65 \mathrm{ppm}$, as well as in ${ }^{13} \mathrm{C}$ NMR spectrum by chemical shifts at 45.23 and $52.04 \mathrm{ppm}$. Regarding the possibility of using synthesized resins as polymeric additives to bitumen-polymeric mixtures, it was found that the addition of $1 \%$ CIRM to the mixtures does not substantially affect the softening temperature, penetration and ductility, but doubles the adhesion to glass.

\section{Acknowledgments}

The work was carried out under financial support of the grant DB/Bitum No. 0117 U 004451 of the Ministry of Education and Science of Ukraine.

\section{References}

[1] McNally T. (Ed.): Polymer Modified Bitumen. Properties and Characterization. Woodhead Publ., 2011.

[2] Airey G.: J. Mater. Sci., 2004, 39, 951.

https://doi.org/10.1023/B:JMSC.0000012927.00747.83

[3] Fang C., Li T., Zhang Z., Jing D.: Polym. Composite., 2008, 29, 500. https://doi.org/10.1002/pc.20390

[4] Pyshyev S., Gunka V., Grytsenko Y., Bratychak M.: Chem. Chem. Technol., 2016, 10, 631.

https://doi.org/10.23939/chcht10.04si.631

[5] Bahl J., Atheya N., Singh H. et al.: Erdoel Kohle, Erdgas,

Petrochem., 1993, 46, 22.

[6] Bratychak M., Chervinskyy T., Astakhova O. et al.: Chem.

Chem. Technol., 2010, 4, 325.

[7] Bratychak M., Grynyshyn O., Astakhova O. et al.: Ecolog. Chem. Eng. S, 2010, 17, 309.

[81 Grynyshyn O., Astakhova O., Chervinskyy T.: Chem. Chem. Technol., 2010, 4, 241.

[9] Strap G., Astakhova O., Lazorko O. et al.: Chem. Chem. Technol., 2013, 7, 279.

[10] Bratychak M., Iatsyshyn O., Shyshchak O. et al.: Chem. Chem. Technol., 2017, 11, 49. https://doi.org/10.23939/chcht11.01.049
[11] Bratychak M., Gagin M., Shyshchak O., Waclawek W.: Chemia i Inzyneria Ekologiczna, 2004, 11, 15.

「12] Bratychak M., Gagin M., Shyshchak O., Waclawek W.: Chemia i Inzyneria Ekologiczna, 2004, 11, 21.

[13] Gagin M., Bratychak M., Shyshchak O., Waclawek W.: Chemia i Inzyneria Ekologiczna, 2004, 11, 27.

$\lceil 14\rceil$ Chervinskyy T., Bratychak M., Gagin M., Waclawek W.: Chemia i Inzyneria Ekologiczna, 2004, 11, 1225.

[15] Skibitskiy V., Grynyshyn O., Bratychak M., Waclawek W.: Chemia i Inzyneria Ekologiczna, 2004, 11, 41.

[16] Bratychak M., Grynyshyn O., Shyshchak O. et al.: Ecolog. Chem. Eng., 2007, 14, 225.

[17] Grynyshyn O., Bratychak M., Krynytskiy V., Donchak V.: Chem. Chem. Technol., 2008, $2,47$.

[18] Wu Y., Li J., Xu J. et al.: J. Shanghai Univ. Engl. Ed., 2010, 14, 313. https://doi.org/10.1007/s11741-010-0651-3

[19] Sokolov V.: Inden-Kumaronovye Smoly. Metalurgia, Moskva 1978.

[20] Pyshyev S., Grytsenko Y., Solodkyy S. et al.: Chem. Chem. Technol., 2015, 9, 359.

[21] Bratychak M., Astakhova O., Shyshchak O. et al.: Chem. Chem. Technol., 2017, 11, 509.

https://doi.org/10.23939/chcht11.04.509

[22] Bratychak M., Ripak O., Namiesnik J. et al.: Chem. Chem. Technol., 2018, 12, 93. https://doi.org/10.23939/chcht12.01.093 [23] https://www.chemicalbook.com/ChemicalProductProperty_ EN_CB3415111.htm.

[24] BS EN 13589:2008. European Standard. Bitumen and bituminous binders. Determination of the tensile properties of modified bitumen by the force ductility method

[25] BS EN 1426:2000. European Standard. Bitumen and bituminous binders. Methods of tests for petroleum and its products. Determination of needle penetration

[26] BS EN 1427:2007. European Standard. Bitumen and bituminous binders. Determination of the softening point. Ring and Ball method [27] BS EN 13614:2011. European Standard. Bitumen and bituminous binders. Determination of adhesivity of ituminous emulstions by water immersion test

Received: December 02, 2017 / Revised: December 20, 2017 / Accepted: March 05, 2018

\section{ОДЕРЖАННЯ ІНДЕН-КУМАРОНОВИХ СМОЛ 3 ЛЕГКОЇ ФРАКЦІЇ КАМ‘ЯНО-ВУГІЛЬНОЇ СМОЛИ 3. ІНДЕН-КУМАРОНОВІ СМОЛИ 3 МЕТАКРИЛАТНИМИ ФРАГМЕНТАМИ}

Анотація. 3 використанням легкої фракиії кам'яновугільної смоли та отриманої на ї̈ основі фракиї, щуо википає за температур 423-463 К, з додаванням метилметакрилату розроблено метод одержання інден-кумаронових смол 3 метакрилатними фрагментами (CIRM). CIRM отримано за радикальною коолігомеризаиією з використанням як ініиіатор 2,2'-азобіс(2-метил-пропіонітрилу). Встановлено вплив кількості ініиіатора, температури та тривалості реакиії на вихід, температуру розм'якшення та молекулярну масу CIRM. Структуру синтезованих CIRM підтверджено IЧ- та ЯMPспектроскопічними дослідженнями. Запропоновано використовувати CIRM як полімерну складову бітум-полімерних сумішей (БПС). Вивчено вплив кількості CIRM, температури та тривалості на основні характеристики БПС.

Ключові слова: інден-кумаронова смола, кам'яновугільна смола, метилметакрилат, азоініціатор, ІЧ-спектроскопія, ЯМР-спектроскопія, бітум-полімерна суміш. 